\title{
Gypsum amendment of arable fields as a water protection measure - farmers' experience, phosphorus reduction potential and associated costs drawn from a large scale pilot
}

\author{
${ }^{1}$ Markku Ollikainen, ${ }^{1}$ Anna-Kaisa Kosenius, ${ }^{1}$ Eliisa Punttila, ${ }^{1}$ Venla Ala-Harja, ${ }^{1}$ Samuli Puroila, \\ ${ }^{2}$ Antti lho and ${ }^{3}$ Petri Ekholm \\ ${ }^{1}$ Department of Economics and Management, University of Helsinki, Finland \\ ${ }^{2}$ Natural Resources Institute (Luke), Helsinki, Finland \\ ${ }^{3}$ Finnish Environment Institute, Helsinki, Finland \\ e-mail: markku.ollikainen@helsinki.fi
}

\begin{abstract}
We organized a large-scale pilot on gypsum amendment of arable fields in southwest Finland, along the River Savijoki to examine its effects on phosphorus loads and aquatic environment, and to assess its feasibility as a water protection measure. This paper reports findings on the feasibility aspects of gypsum amendment covering logistics and costs of spreading, abatement potential and farmers' experience. We found that farmers perceived gypsum amendment positively and the costs of reducing phosphorus are low relative to other measures available in agriculture. Gypsum amendment suits well to 0.5 million hectares of arable land in southern Finland. Gypsum could potentially contribute considerably to the achievement of phosphorus reduction targets of the Baltic Sea Action Plan if applied in all countries having clay soils.
\end{abstract}

Key words: phosphorus loads, eutrophication, co-creation, agri-environmental policy, Baltic Sea

\section{Introduction}

The Baltic Sea is one of the most polluted seas in the world. It suffers from eutrophication caused by excessive nutrient loads from point sources and non-point sources. Agriculture is the largest polluting sector in the Baltic Sea region. In Finland, the share of agriculture in total anthropogenic phosphorus load ranges from $52 \%$ to $78 \%$ among different sub-basins of the Baltic Sea (Uusitalo et al. 2007).

To achieve the good ecological status of the sea, the Baltic Sea region countries have accepted the Baltic Sea Action Plan requiring annually a reduction of 15000 tons of phosphorus and 135000 tons of nitrogen loads. Reducing agricultural loads has proven to be a big challenge all over the world. Reasons for this failure are plentiful: low level of national ambition, lack of proper incentives in agriculture, vaguely designed policies and low performance of some favored measures especially in reducing phosphorus (Shortle and Horan 2017, Ollikainen et al. 2019).

Inventing new and more efficient water protection measures would help agriculture to improve its performance in water protection. A good candidate for a new and efficient measure targeting phosphorus loads from clayey soils is gypsum amendment of arable fields. Gypsum $\left(\mathrm{CaSO}_{4} \cdot 2 \mathrm{H}_{2} \mathrm{O}\right)$ has been used for soil improvement for centuries, but its role as a water protection measure was discovered only recently (Aura et al. 2006, Bryant et al. 2012, Jaakkola et al. 2012, Uusitalo et al. 2012, Iho et al. 2014, King et al. 2016). When spread onto fields, gypsum increases the ionic strength of soil solution. It gives rise to the formation of larger aggregates of soil particles and calcium bridges and binds phosphorus more tightly in soil particles. Therefore, erosion and the loss of particulate and dissolved phosphorus decreases, but phosphorus still remains available to plants. These beneficial effects take place immediately after the dissolution of gypsum and are assumed to last about five years according to a catchment study performed on a clayey area in southern Finland (Ekholm et al., personal communication). These effects have been quantified by tests on laboratory, field and catchment scales (Ekholm et al. 2012, Uusitalo et al. 2012). The catchment study demonstrated a $55 \%$ reduction in particulate phosphorus and $25 \%$ in dissolved phosphorus loads during three years after the amendment (Ekholm et al. 2012).

To assess the social and economic feasibility of gypsum amendment, a large-scale pilot, "Saving the Archipelago Sea by applying gypsum to agricultural fields" (SAVE) was organized in 2016-2018 in the River Savijoki in southwest Finland, located in the catchment of the Archipelago Sea, a very unique part of the Baltic Sea. The pilot examined a large variety of social, logistical and economic issues relating to gypsum amendment. Also, it focused on the unstudied issues of the impacts of gypsum (sulfur) on the aquatic environment, and on soils and vegetation, and ascertained the magnitude of phosphorus load reduction measured in previous pilots. To determine the 


\section{AGRICULTURAL AND FOOD SCIENCE}

M. Ollikainen et al. (2020) 29: 383-394

overall phosphorus reduction potential of gypsum amendment, we also estimated the amount of arable land areas, where gypsum can be applied. Finally, as a large-scale pilot, SAVE project was supposed to meet all possible challenges and legal restrictions that gypsum amendment at a national scale would encounter.

While local farmers were the most important stakeholder group, being responsible for the actual spreading effort of gypsum, other important stakeholders were agents in the logistical chain, environmental authorities, cities and local people. The social acceptability of gypsum amendment was assessed in close cooperation with these stakeholders

SAVE pilot project gave a high importance on cooperation between scientists, farmers and other stakeholders, such as the producers of gypsum, traders, NGOs and public authorities. Altogether 55 farmers participated in the pilot. The pilot project created an open collaborative interactive working environment and welcomed farmers' experience and knowhow to further develop all potentials of the gypsum concept. Their perceptions and views were collected during the 3-year project period, starting from the contacts to invite farmers to participate and finishing with the third annual survey conducted at the end of the third project year.

In this paper, we explore the general feasibility gypsum amendment, and social and cognitive processes associated with the gypsum pilot. We report how the farmers gathered knowledge and experience when testing a new agri-environmental measure and describe their perceptions of gypsum amendment and its applicability on a large scale. We also provide figures on the associated logistics and the abatement potential, the latter based on the calculations of phosphorus load reductions, abatement costs and abatement potential. We also discuss the suitability of gypsum amendment of fields as a new measure in the Finnish agri-environmental scheme and the features of European Union Common Agricultural Policy (CAP) framework from water protection angle.

The natural science findings of the pilot provide a background for this paper but will be subject of other papers. Preliminary findings concerning phosphorus runoff and impacts of sulfates in aquatic environment are reported in Ollikainen et al. (2018). These findings ascertain that gypsum reduces phosphorus runoff at least by $50 \%$. No negative impacts of sulfates on adult thick-shelled river mussels, or the survival of their larvae were found. Sulfates had no effects on fish stocks, reproduction of trout and on the growth of antifever fontinalis moss. Finally, gypsum reduces considerably dissolved and particulate carbon runoff, which is beneficial for both yields and climate. The pilot did not assess climate impacts of gypsum. Gypsum is a side product of phosphoric acid industry and thus, could be treated as zero carbon product. Depending on how emissions from the production of phosphoric acid are attributed to gypsum, four tons of gypsum would entail about 50-400 kg CO2-equivalent emissions.

\section{The pilot, methods and data}

\section{Study area and logistics}

The pilot area is located in the valley of the River Savijoki in the municipalities of Lieto and Aura and the city of Paimio, in southwest Finland. The river is about $28 \mathrm{~km}$ long, and its river basin covers an area of $130.5 \mathrm{~km}^{2}$. The Savijoki meanders across an old agricultural landscape. During rainy seasons and snow-melt periods, its flow drastically increases and the water becomes turbid due to erosion of clayey soils. The river belongs to medium-sized rivers in regions with clay soils. Its ecological state is poor, the second lowest category in a 5-level classification. The river is a tributary of the River Aurajoki discharging into the Archipelago Sea, which suffers from severe nutrient enrichment and eutrophication.

The River Savijoki (Fig. 1) is ideal for a large-scale pilot due to its size and to the fact that most of the fields are on clayey soils and the characteristics of the area are well-known. The upper reaches were left as a control area, where gypsum was not used. This part of the Savijoki watershed has been monitored since the 1960s, providing excellent background data. The middle reaches immediately downstream from the control area formed the pilot area, where water quality and environmental effects were also monitored and measured.

A total of $51 \%$ (1494 hectares) of the arable area within the gypsum amendment area was treated with gypsum. In terms of farms, 53 out of 107 farmers in the area participated in the pilot area. In addition, outside the Savijoki catchment area, two farmers (65 hectares of arable fields) participated in the pilot. A farm advisor visited all interested farms during late spring 2016 and checked the eligibility of all field parcels that the farmer was willing to enroll in the pilot. After the decision, an agreement was made between the farms and the SAVE project on the 


\section{AGRICULTURAL AND FOOD SCIENCE}

delivery and spreading. Many organic farmers would have been willing to participate in the pilot. This was not possible, however: The gypsum offered in the pilot was a by-product of phosphorus acid industry and its application would have violated the CAP regulations on organic farming.

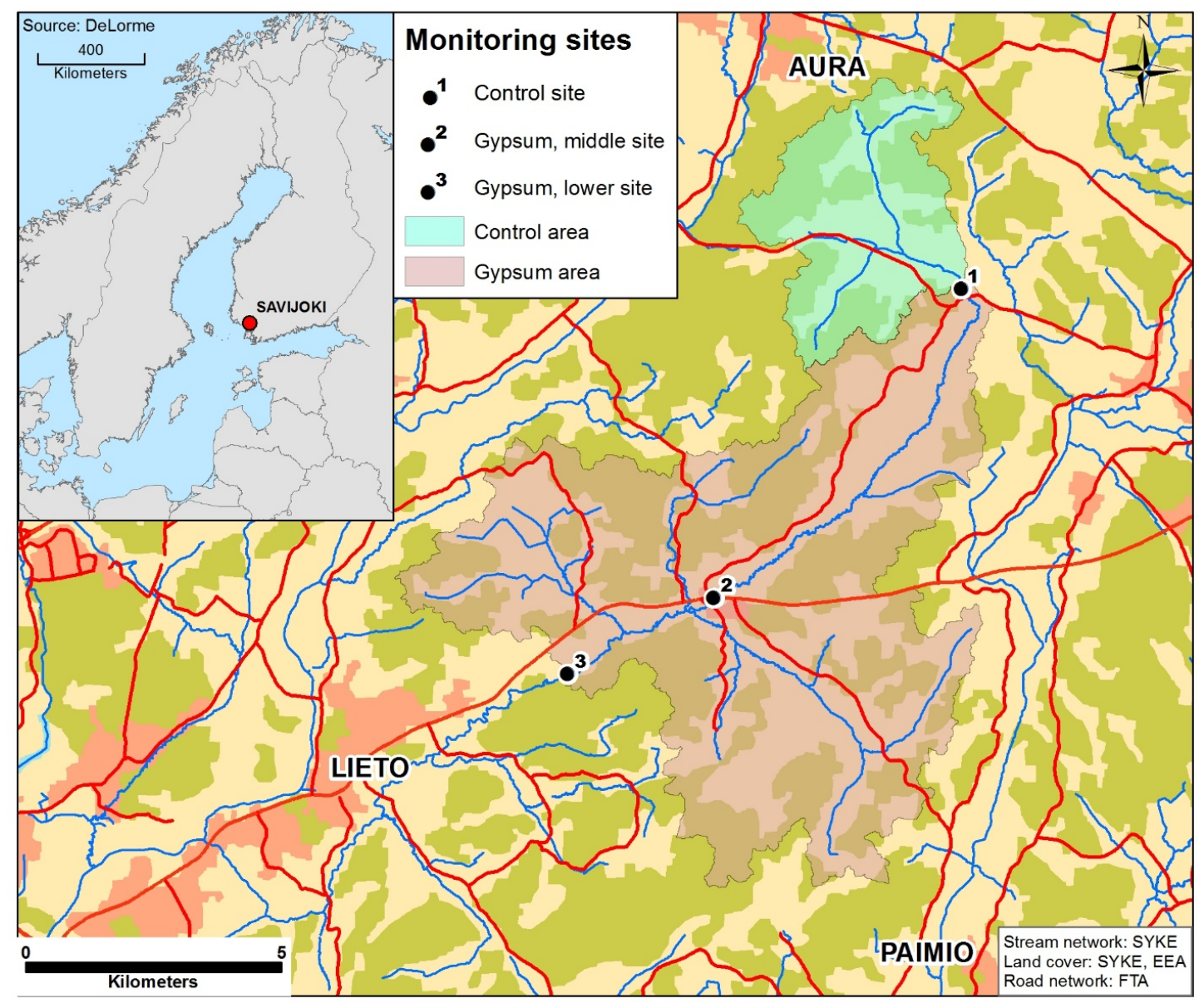

Fig. 1. The gypsum amendment area, the control area, and the three monitoring sites along the River Savijoki

In autumn 2016, 1559 hectares of fields were treated with four tons of gypsum per hectare. Delivery of gypsum was handled through an agricultural retailer. The delivery took place in late summer and autumn 2016. As Figure 2 suggests, the most hectic time of delivery took place during September 5-11 (1407 tons, week 36) and September 12-18 (2091 tons, week 37). The average delivery was 114 tons per farm with 1227 as the maximum and 13 tons as the minimum. In total, 6270 tons were delivered in 144 trucks by October 2016, which makes on average 43.5 tons of gypsum per truck.

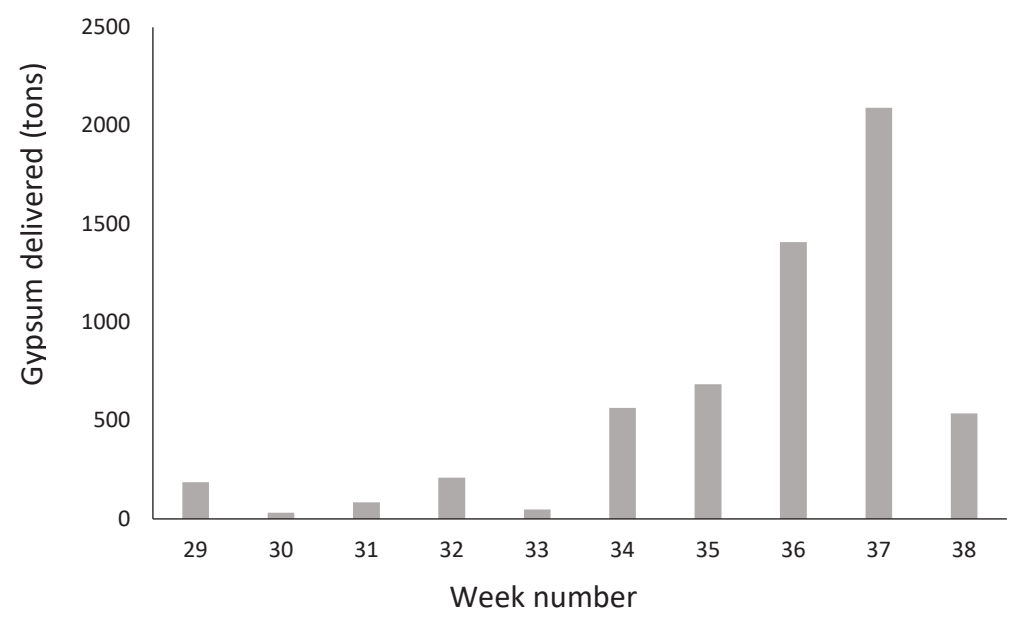

Fig. 2. Logistic challenge: weekly amounts of delivered gypsum during summer and autumn 2016 (Information source: Movere) 


\section{AGRICULTURAL AND FOOD SCIENCE}

M. Ollikainen et al. (2020) 29: 383-394

Gypsum delivered to the pilot area was a by-product of the phosphoric acid industry from Siilinjärvi. Industry uses in its production magmatic apatite, which contains no harmful substances. The amount of accumulated gypsum reserves is so great it could easily provide gypsum to the whole potential spreading area in Finland.

\section{Measuring farmer experiences and perceptions}

Our analysis of farmers' perceptions bases on quantitative data from surveys and on qualitative workshop data. During the three-year project, we elicited participants' views on the gypsum amendment and its suitability as a water protection measure with a series of structured surveys conducted annually, at the end of the years 2016, 2017 and 2018. At the end of the second project year, we organized a farmer workshop to collect suggestions specifically on the logistics and the funding of the gypsum amendment.

Each year, the farmer survey data were collected during a ten-week period online using the Surveypal platform and by mail and, in few cases, phone interviews accompanied by the mail survey received by the respondent. The mixed-mode collection was applied in order to gather the largest possible data set.

All three surveys contained questions on the allocation of field parcel between crops and on the adopted farming practices during the previous year both at the farm level and relating fields treated with gypsum. The farmers were asked to provide self-assessment of learning about various aspects of gypsum amendment. Questions on farmer and farm characteristics, attitudes and concerns on the gypsum amendment of fields as well as its introduction to the agri-environmental payment scheme served the policy reform purposes.

In addition to these parts common to all questionnaires through the years, annual surveys focused on special topics of interest. In 2016 right after spreading of gypsum on fields, the farmers were asked about their motivations to participate in the pilot, analyzed in Kosenius and Ollikainen (2019), and about their experiences on the delivery of gypsum and its spreading. In 2017 and 2018, the focus was on their experiences about the positive, negative or neutral effects of gypsum amendment in soil, yield, and the neighboring water environment. As an attempt to increase reliability of these observations, they were accompanied with information on farmers' level of experience in assessing these effects on their fields.

All attitudinal statements were assessed in a 7-point Likert scales. The same applied to the questions concerning learning about a new water protection measure. Regarding the assessment of learning, in communication studies, business studies and psychology, learners can be asked to self-assess either their current level of knowledge or the extent of which they have increased their knowledge during the field experiment (e.g. Sitzmann et al. 2010). While the former requires a judgement against an external standard, our farmer survey relies on the self-referential judgement. Regarding all attitudinal questions, the differences between subsequent years in the panel data were estimated with Wilcoxon signed-rank tests for the mean values of attitudinal variables, reflecting the extent of agreement with the statement, and McNemar tests for dichotomous variables, i.e. the shares of farmers who agree with the statements in the 7-point scale.

The first survey, sent to 55 participants in 2016, resulted in 48 responses, corresponding to a $87 \%$ response rate. In order to gather a panel data, the second and third surveys targeted the respondents of previous survey(s). After few drop-outs and one response that became unintentionally destroyed due to a technical problem in 2017, the final number of respondents in the panel analysis (including three answers per respondent) was 43, corresponding to a $78 \%$ response rate of the total sampled population. In the third survey, $9 \%$ of responses was obtained by mail while the percentage in the first survey was $15 \%$.

Regarding the descriptive characteristics of farms and demographic factors of farmers (Table 1), in comparison to average farmers in the county of Southwest Finland, the survey respondents (and the farmers participating in the pilot) have larger farms and larger shares of leased field area out of the total field area. Also, survey respondents more likely intended to continue farming for at least six years, in comparison to the country average (46.5\%; Kallinen et al. 2016). This is not a surprise, because the pilot area belongs to the most favorable area for agriculture in Finland.

Apart from collecting the farmer survey data, the farmer workshop was organized in November 2017 to focus on the organization of logistics and ways of covering the costs of the gypsum amendment. Eleven farmers were divided into three groups, in which we facilitated group discussions based on structured survey questions as follows. Regarding the funding, farmers were asked for suggestions on how the gypsum treatment could be included 


\section{AGRICULTURAL AND FOOD SCIENCE}

M. Ollikainen et al. (2020) 29: 383-394

in the current agri-environmental support system, on the best way to organize the payment system (including the timing of payment), and what would be the easiest way for farmers to inform about their willingness to enroll. Moreover, the questions concerned farmers' and authorities' responsibilities in checking the eligibility of the parcels selected for gypsum treatment and the need for relevant information for that purpose. To account for potential risks in the planned schedule of spreading, we asked for suggestions on how the system should account for the situation when the gypsum could not be spread on time as planned. The questions regarding logistics included the storage of gypsum in farms, the organization of the spreading of gypsum in the Archipelago Sea catchment area during several years instead of one year, and how, in this case, the implementation should be planned, and what would be the best way to inform farmers about gypsum.

\begin{tabular}{|c|c|c|}
\hline & $\begin{array}{l}\text { Sample } \\
(n=43)\end{array}$ & $\begin{array}{c}\text { County } \\
(n=4536)\end{array}$ \\
\hline & Mean & Mean \\
\hline \multicolumn{3}{|l|}{ Farm characteristics } \\
\hline Total field area (own and leased) of farm (ha, mean) & 118.1 & 53.1 \\
\hline Percentage of field area leased & $47.6 \%$ & $32 \%$ \\
\hline Crop production & $90.7 \%$ & na \\
\hline Participation in current agri-environmental payment scheme & $90.7 \%$ & na \\
\hline Main cultivation practice: autumn ploughing & $46.5 \%$ & na \\
\hline Main cultivation practice: reduced tillage & $41.9 \%$ & na \\
\hline Main cultivation practice: no-tillage & $11.6 \%$ & na \\
\hline \multicolumn{3}{|l|}{ Farmer characteristics } \\
\hline Age (yrs, mean) & 51.3 & 51 \\
\hline Age group $<35$ years & $7.0 \%$ & $8.2 \%$ \\
\hline Age group $35-49$ years & $34.9 \%$ & $33.8 \%$ \\
\hline Age group $50-64$ years & $46.5 \%$ & $46.0 \%$ \\
\hline Age group $>65$ years & $11.6 \%$ & $12.0 \%$ \\
\hline Experience in agriculture (yrs, mean) & 27.0 & na \\
\hline Agricultural education: none & $25.6 \%$ & na \\
\hline Full-time farmer & $23.3 \%$ & na \\
\hline Plans to continue farming at least $6 \mathrm{yrs}$ & $77.8 \%$ & na \\
\hline Percentage of agricultural income: $>75 \%$ & $23.3 \%$ & na \\
\hline Percentage of agricultural income: $50-74 \%$ & $27.9 \%$ & na \\
\hline Percentage of agricultural income: $25-49 \%$ & $16.3 \%$ & na \\
\hline Percentage of agricultural income: $<25 \%$ & $32.6 \%$ & na \\
\hline Percentage of agricultural income in household income & na & $30.6 \%$ \\
\hline
\end{tabular}

\section{Farmers' perceptions on gypsum amendment \\ Experience on spreading gypsum}

The farmer survey 2016 focused on collecting the experiences of farmers on the delivery and spreading of gypsum. Based on all responses to that survey $(n=48)$, these phases of the pilot were successful in terms of timing and quality of spreading. No more than $4-21 \%$ of farmers reported problems in some of the work phases: (delivery, storage, transport of gypsum on the farm, spreading and scheduling with other work in fields) or the equipment used for spreading. The problems that occurred were related to the limited time frame of spreading or weather conditions. The most preferred conditions for gypsum amendment are early harvest and autumn with no heavy rains before and during the spreading of gypsum. 


\section{AGRICULTURAL AND FOOD SCIENCE}

M. Ollikainen et al. (2020) 29: 383-394

In more detail, the majority of participants (93.6\%) reported that the delivery of gypsum took place on time, as agreed, and that they managed to spread gypsum as scheduled (93.6\%). Gypsum was most often stored close to the field parcels to be treated with gypsum, only $19.1 \%$ had to transport gypsum on farm. The spreading was performed by contractors ( $83 \%$ of farms), and only few participants $(10.4 \%)$ did not know which spreading equipment the contractor used. The contractors were either neighbours (31.9\%), previous co-operators (34.0\%) or found with help of the SAVE pilot project (27.7\%). Most often the spreading equipment of dried manure (50\%) or humid lime (37.5\%) was used, and for the majority (87.2\%), the equipment suited well the spreading.

For most farmers, spreading the gypsum went well (68.1\%) or moderately (29.8\%) along with other tasks on farms. The significance of scheduling, indicated as the most challenging phase, would have been even more critical if the gypsum spreading took place during a rainier autumn than 2016, which was extraordinary dry and warm. Based on the professional experience of farmers, they stressed in an open question concerning gypsum amendment during a "normal" autumn that when the time window for spreading gypsum during the best possible weather conditions is narrow, accounting also for other field work to be done, the gypsum should be delivered exactly on time. Moreover, risks concerning possible damages to farm roads and fields caused by heavy trucks and spreading equipment, the possible need for transportation on the farm, potential need for covering or storing the gypsum piles, the risk of the break-down of the equipment and increasing overall costs were brought up concerning the more challenging weather conditions. In addition to concerns related to weather, survey respondents listed suggestions to develop the gypsum concept, for instance, further investigation for local storage for gypsum, possibility of wintertime spreading and using more suitable trucks for small local roads. These ideas expressed during the first project year were considered further when creating the suggestions for large-scale gypsum amendment of arable fields.

\section{Farmers' learning and observations}

While testing a new measure for water protection, farmers were subject to learning on several gypsum related aspects during a three-year pilot. The most important learning outcomes during the pilot project were measured based on farmers' own assessment by the share of farmers who responded one of the two categories on 7-point scale that reflect the most increasing knowledge. Based on the last farmer survey in 2018 ( $n=43)$, the most important learning outcomes were related to their knowledge on spreading gypsum in practice (50\%), the spreading equipment (40.9\%) and the effect of gypsum on phosphorus losses (34.1\%). Some increase in farmers' understanding was created concerning the effect of gypsum on soil chemistry and the suitability of gypsum for fields growing different plant species. The least was learnt about the effect of gypsum on the ability of plants to use nutrients or on the groundwater, the potential sulfur deficit in soil and the impact of sulfate on bodies of water.

The variety of plants and farming practices provides a promising base for the wide assessment of the potential effects of gypsum amendment on yield and soil that goes beyond the farmers' subjective assessment on their gypsum amended fields (Table 2) after one and two growing seasons. However, the number of farmers in observation categories vary, ranging from 3 (oil plants in 2017 and legumes in 2018) to 33 (spring crops and small puddles in fields in 2017). Given that all percentages add up to more than $100 \%$, one farmer has cultivated more than one plant and applied more than one farming practice in their gypsum treated field area.

The majority of farmers provided their observations about the effects of gypsum amendment on yield, soil and water quality, and most often, the effects were considered neutral. None of the pilot farmers, except for one in 2018, reported negative effects. After one growing season, every third farmer reported positive effects on yields of oil plants and every fifth on yields of legumes and spring crops. The observed increase of yields in some fields may be due to lack of sulphur in soils indicating that these fields did not have a good balance of required nutrients. Out of cultivated plants, the effect of gypsum amendment on spring crops was assessed most often and with the highest self-estimated assessment experience score, reflecting the highest reliability.

As for farming practices, the share of farmers who ploughed their fields or relied in reduced tillage and experienced positive impacts on soil ranged from $35.5 \%$ to $50.0 \%$. As to no-tillage fields, farmers reported the effects least actively, associated with lowest experience score, and the reported positive effects were rare. Concerning water quality after one growing season, farmers observed most frequently the puddles on their fields, followed by water quality in ditches and the River Savijoki. Interestingly, farmers do not observing water quality in a routinely systematic way. 
Table 2. Farmers' observations of effects of gypsum amendment on yield, soil and water quality (2017: $n=46,2018: n=43$ )

\begin{tabular}{|c|c|c|c|c|}
\hline Effect of gypsum & $\begin{array}{c}\% \text { farmers involved } \\
2017 / 2018\end{array}$ & $\begin{array}{l}\text { \% farmers providing } \\
\text { assessment 2017/2018 }\end{array}$ & $\begin{array}{l}\% \text { positive effect (out of those } \\
\text { who assessed) } 2017 / 2018\end{array}$ & $\begin{array}{c}\text { Self-estimated } \\
\text { assessment experience } \\
\text { (mean) }{ }^{*}\end{array}$ \\
\hline \multicolumn{5}{|l|}{ Yield } \\
\hline Autumn crops & $32.6 / 15.9$ & 32.6 / 11.4 & $6.7 / 20.0$ & 0.85 \\
\hline Spring crops & 84.8 / 81.8 & 71.7 / 47.7 & $21.2 / 14.3$ & 1.54 \\
\hline Oil plants & $13.0 / 15.9$ & $6.5 / 11.4$ & $33.3 / 20.0$ & 0.74 \\
\hline Legumes & $15.2 / 20.5$ & 10.9 / 6.8 & $20.0 / 0.0$ & 0.58 \\
\hline \multicolumn{5}{|l|}{ Soil quality } \\
\hline Ploughed & 69.6 / 50.0 & 54.4 / 31.8 & $44.0 / 35.7$ & 1.28 \\
\hline Reduced tillage & $43.5 / 56.8$ & $37.0 / 45.5$ & $35.3 / 50.0$ & 1.15 \\
\hline No-tillage & $54.4 / 56.8$ & $26.1 / 9.1$ & $8.3 / 25.0$ & 0.74 \\
\hline \multicolumn{5}{|l|}{ Water quality } \\
\hline Puddles in fields & na & 73.9 / na & 45.5 / na & 1.28 \\
\hline Ditches & na & 58.7 / na & 37.0 / na & 1.08 \\
\hline River & na & 39.1 / na & 38.9 / na & 0.88 \\
\hline
\end{tabular}

* = scale in assessment experience from 0 (no experience) to 3

\section{Perceptions and concerns on gypsum amendment}

A series of three annual surveys allows for exploring whether any of the attitudes concerning gypsum amendment of fields evolved over the three project years (Table 3). A comparison of the first and the last survey suggests that around a half of farmers considered the gypsum amendment as an easy measure for water protection and indicated being proud of participating in testing a new water protection measure. However, a slight majority would need more experience in gypsum amendment of fields as a conservation measure before being able to use it reliably. The Wilcoxon signed-rank test or the McNemar test showed no statistically significant differences between years in how farmers perceived gypsum amendment as a measure in water protection toolbox. Importantly, active participation in the development phase of a new water protection measure hadstrengthened the respondents' perception on their frequency of trying new methods $(Z=-2.052 ; p=0.040)$ and on the feeling of reward when sharing one's ideas $(Z=-2.314 ; p=0.021)$.

Table 3. Farmers' perceptions and concerns on gypsum amendment; answers on 7-point Likert scale

\begin{tabular}{|c|c|c|}
\hline Statement & \% agree 2016 / 2018 & Mean value 2016 / 2018 \\
\hline I'm proud of participating in this project & $41.9 / 51.2$ & $4.44 / 4.72$ \\
\hline $\begin{array}{l}\text { After the pilot, I will need more experience in gypsum treatment as a } \\
\text { conservation measure before being able to use it reliably }\end{array}$ & $65.1 / 53.5$ & $4.02 / 4.53$ \\
\hline I often try new agricultural methods & $37.2 / 53.5$ & $4.05 / 4.53^{* *}$ \\
\hline I feel reward when sharing my ideas & $39.5 / 53.5$ & $4.07 / 4.56 * *$ \\
\hline \multicolumn{3}{|l|}{ Concerns } \\
\hline Costs of gypsum application on fields that will not be covered by the payment & 67.4 / 76.7 & $4.91 / 5.51$ \\
\hline Soil hardens after gypsum treatment & $51.2 / 23.3^{* * *}$ & $4.02 / 3.65$ \\
\hline Smaller yield next year due to gypsum & $46.5 / 30.2$ & 4.14 / 3.81 \\
\hline
\end{tabular}

As to four concerns about testing the new measure for water protection expressed by farmers when invited to participate in the gypsum pilot, the most important concern was the costs of spreading gypsum on fields that will not be compensated, followed by the impact of the introduction of the gypsum amendment in the 
agri-environmental payment scheme on current agri-environmental subsidies, the reduction in yields after gypsum amendment of fields and soil compaction. While the economic concerns were through the project on average somewhat higher than agronomic concerns, the only statistically significant difference between two years was the decrease in the proportion of farmers who were concerned on soil compaction $(p=0.004)$.

Right after spreading gypsum on fields, farmers felt that their opinions had been heard in the pilot work (83.7\% in 2016) and that they had impacted the development of the gypsum concept towards a new water protection measure (69.8\%). Every fifth farmer (20.9\%) did not believe that gypsum amendment would lead to a significant reduction of agricultural nutrient loading and a third (30.2\%) expressed distrust in the other farmers' willingness to adopt the gypsum treatment of fields. At the end of the SAVE project, a large majority of farmers stated that they would use gypsum amendment if it were an option in the Finnish agri-environmental scheme. Hence, it might be presumed that majority of them also support the introduction of the gypsum amendment of field into the toolkit of water protection measures. A part from the actual spreading of gypsum, all respondents recommend farmers to participate in pilot projects similar to the SAVE project. To note is that this recommendation was measured with a negative statement on which no one agreed, except for one respondent who had answered "Strongly agree" to each statement, indicating the lack of reading and seriously considering the statements.

\title{
Large-scale application: potential and costs of phosphorus load reduction
}

\author{
Phosphorus load reduction potential of gypsum
}

Gypsum performs best on clay soils. We estimated the part of cultivated land area in Finland applicable for gypsum amendment in three sub-basins of the Baltic Sea: the Bothnian Sea, the Archipelago Sea and the Gulf of Finland. The potential area was estimated by excluding the areas where gypsum amendment is not recommended such as fresh water areas or acid sulfate soils (for details see Ollikainen et al. 2018). Table 4 indicates the potential areas and the estimates for reduction in phosphorus loads. A reduction of around $50 \%$ in total phosphorus loads has been measured so far in the pilot area, and the measurement continues till 2020. Therefore, we applied the previously established reduction rates: $25 \%$ for dissolved reactive phosphorous and $50 \%$ for particulate phosphorous suggested by Ekholm et al. (2012). According to this tentative estimate, gypsum amendment could reduce the phosphorus load reaching the Baltic Sea by 300 tons a year in Finland. This reduction would help Finland to achieve the phosphorus reduction targets set by the HELCOM Baltic Sea Action Plan and the Finnish Marine Strategy (Laamanen 2016).

In the Archipelago Sea gypsum amendment would provide the targeted reduction and in the Bothnian Sea the reduction would exceed the target. In contrast, the Gulf of Finland would require additional measures, especially to reduce those loads coming from inlands and through the Lake Ladoga. For these loads other measures than gypsum, such as structural liming, would be needed. The reason is as follows. Once spread on fields, the dissolution of gypsum releases sulfate to water. Sea water contains naturally sulfate, so, it is safe to use gypsum in arable fields along waterways running to the sea. Gypsum amendment is not recommended on fields locating close to lakes and other freshwater.

Table 4. Total area of cultivated land, area suitable for gypsum amendment, annual reduction in phosphorus loads and annual phosphorus load reduction target in three drainage basins in Finland

\begin{tabular}{|c|c|c|c|c|}
\hline Drainage basin & $\begin{array}{l}\text { Area of cultivated land } \\
\text { (ha) }\end{array}$ & $\begin{array}{l}\text { Area suitable for gypsum } \\
\text { (ha) }\end{array}$ & $\begin{array}{l}\text { P-load reduction } \\
\left(\mathrm{t} \text { year }{ }^{-1}\right)\end{array}$ & $\begin{array}{l}\text { P-load reduction target } \\
\left.\text { (t year }{ }^{-1}\right)\end{array}$ \\
\hline Bothnian Sea & 680000 & 240000 & 132 & 60 \\
\hline Archipelago Sea & 220000 & 150000 & 98 & 100 \\
\hline Gulf of Finland & 480000 & 150000 & 83 & 170 \\
\hline Total & 1380000 & 540000 & 312 & 330 \\
\hline
\end{tabular}

As to an Archipelago Sea catchment-wide gypsum amendment, experience from logistics demonstrated that transport capacity poses some limits on the areas that can be treated per season. By our estimates, by current logistical systems, 50000-80000 hectares can be treated per season. This entails, using the gypsum amount of four tons per hectare and on average 43.5 tons of gypsum in one truck, 31-49 truckloads per day within 5 months (using railways becomes possible with minor investment in the facilities of the supplier of gypsum, also shipping provides a feasible alternative for transport). For the drainage basin of the Archipelago Sea with 150000 hectares of field suitable for gypsum amendment, the transport capacity indicates that all eligible fields can be treated within 2-3 years. 


\section{AGRICULTURAL AND FOOD SCIENCE}

M. Ollikainen et al. (2020) 29: 383-394

Gypsum amendment reduces phosphorus loading quickly but its effect is short-lived. Given that gypsum amendment reduces phosphorus loads approximately by five years, treatment should be repeated by $2-3$ times. During this 15-20 year time span tight phosphorus fertilization limits would reduce soil phosphorus reserves decreasing especially runoff of dissolved reactive phosphorus to an extent that possibly no further amendment is needed to achieve water protection targets.

Table 5 provides our crude estimates concerning the potential of gypsum amendment in Finland, Sweden, Denmark and Poland, which would lead to an annual reduction of 1500 tons. The estimate is based on the estimated share of phosphorus loads from each country's area of clayey soils anda conservative reduction rate for gypsum amendment. Achieving the estimated reductions in Finland or at the Baltic Sea level requires, however, that farmers at a large scale participate in gypsum amendment and that society provides financial support for this investment in water protection.

\begin{tabular}{|c|c|c|c|}
\hline Country & P loads from agriculture & Load from clay soils & P-reduction ( t year $^{-1}$ ) \\
\hline Finland & 1700 & 1190 & 300 \\
\hline Denmark & 500 & 350 & 100 \\
\hline Poland & 5200 & 3540 & 1040 \\
\hline Sweden & 600 & 420 & 120 \\
\hline Total & 8000 & 5500 & 1560 \\
\hline
\end{tabular}

The estimated reduction makes $10 \%$ of BSAP reduction target for phosphorus. Data on soil phosphorus values in these countries and on the erosion sensitivity of soils would be needed to provide more accurate estimates on the reduction potential. Also, field studies on the impacts of gypsum would be an interesting and useful contribution for water policies in the Baltic Sea region.

\section{Estimates of phosphorus abatement cost of gypsum amendment}

The costs of gypsum amendment consist of three basic items: price of gypsum, its delivery costs to farms and the costs of spreading (either by the farmer or a contractor). Ordinary lime and manure spreading machines work well in spreading, thus, no special investment in new machinery is needed. Gypsum does not entail any reduction in farm revenue, as it has no negative impacts on yields and does not require any exclusion of arable land from production. Under general good management practices it does not increase yields and revenues either. By our bookkeeping, the average cost of gypsum amendment was $217 € \mathrm{ha}^{-1}$, of which the cost of gypsum and its transport was $172 €$ ha $^{-1}$ and its spreading on fields $45 €$ ha $^{-1}$. The most expensive delivery (including cost of gypsum and its transport) of gypsum was $218 € \mathrm{ha}^{-1}$ and the cheapest was $129 € \mathrm{ha}^{-1}$.

We examined how the actual costs depend on the size of field parcels subject to gypsum amendment per one farm and found that the size really impacts the costs (Fig. 3). With regard to field parcels less than 10 hectares, cost increased exponentially with decreasing parcel size, whereas cost remain rather constant for larger areas. This suggests that for a given conservation budget and average fields, it is cost-efficient to enrol field parcels that are larger than 5-8 hectares.

We take $217 €$ ha $^{-1}$ as the average cost and use as reductions rates $25 \%$ for dissolved reactive phosphorus and $50 \%$ for particulate phosphorus. Assuming further that the reductive impact of gypsum takes place and, referring to previous pilots, remains constant for 5 years, we find that the cost of reducing phosphorus load in agriculture is around $70 €$ per kilogram of phosphorus reduced. Note that the existing means of reducing the phosphorus load in the short run, such as increasing the size of buffer strips, establishing wetlands would be more expensive: the suggested marginal costs for 30\% reduction in P loads are over $200 €$ (Hyytiäinen and Ollikainen 2012, Lötjönen and Ollikainen 2019). Efficient logistics and more efficient spreading methods may decrease the costs. 


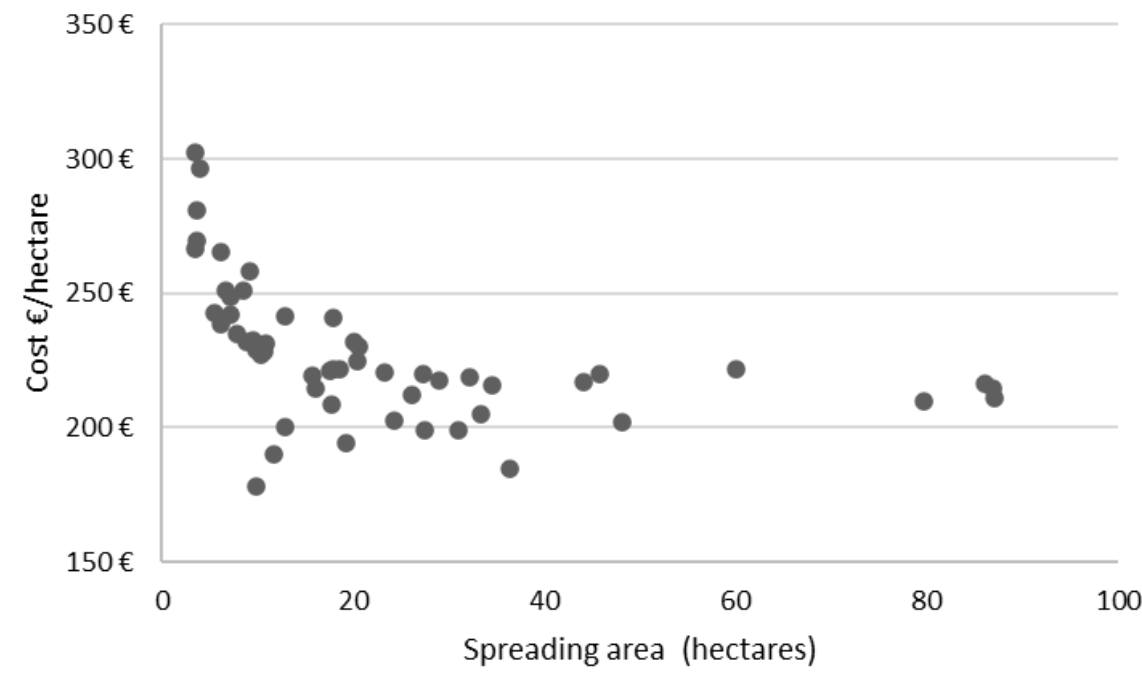

Fig. 3. Costs of gypsum amendment (euros/hectare) as a function of the area treated by gypsum per farm (hectares)

\section{Phosphorus policy considerations}

Gypsum amendment of arable fields is fundamentally an investment in the reduction of phosphorus loads. It has relatively high initial investment costs, while benefits from nutrient abatement accrue over a longer time horizon (e.g. Kost et al. 2018). Given that gypsum does not provide private benefits under the baseline management practices, farmers have no incentives to invest in gypsum amendment in the absence of a voluntary or mandatory policy. EU's Common Agricultural Policy (CAP) is based on farmers' voluntary participation and payments for adopting best management practices for water protection.

The CAP policy was taken as the background in a facilitated farmer workshop organized a year after the gypsum amendment, focusing on logistics and funding, two specific challenges became very visible. First, the conventional agri-environmental payment schemes promoting water protection rely on annual area-based payments for taking annually environmental measures. Gypsum amendment does not suit well to this framework, thus providing a special challenge to EU'S CAP policies. Another challenge related to the current EU/CAP framework, revealed by the experiences from the SAVE project is that in the Savijoki pilot area, the largest farms would have faced the requirement of arranging a public procurement, as the investment in gypsum amendment exceeded the limit after which procurement becomes mandatory by the EU legislation. Obviously, this requirement for private farms is very restrictive. Farms seldom have neither capacity nor willingness to arrange EU wide procurements. This would effectively hinder the participation of larger farms in gypsum amendment or any other water protection investment.

In farmer workshop, deep discussions on how to include gypsum amendment in agricultural support systems came up with a solution: the government takes care of procurements and uses the allocated water protection budget to directly pay for the investment, that is, for the delivery. In this arrangement, farmers would indicate in an electronic system which parcels they would enrol and the system automatically would check their eligibility. This type of arrangement would solve both liquidity and procurement problems. The gypsum amendment that involves high up-front costs and high costs for larger farms, however, is a special case. But there are most likely many other cases for water protection in agriculture, where up-front investments challenge current CAP regulation. Therefore, a more general solution is needed, which fits to a larger set of possible water protection investments. Therefore, one needs also to examine the CAP frame from a broader angle.

\section{Conclusions}

We reported experience from a large-scale pilot on a new water protection measure, gypsum amendment of arable fields. The aim of the pilot was to investigate logistics, costs, phosphorus load reduction potential, agronomic and environmental impacts and social acceptance in the co-creation with farmers and other stakeholders. Our main focus was on the social acceptability: farmers' perceptions of gypsum amendment, reduction potential and abatement costs. 


\section{AGRICULTURAL AND FOOD SCIENCE}

M. Ollikainen et al. (2020) 29: 383-394

Our tentative estimates based on the first three years of data suggest that gypsum amendment reduces phosphorus loads at least by 50\% with a cost of 60-70 € per reduced kilogram of phosphorus. Thus, gypsum is the cheaper and more effective water protection measure for agriculture than the currently used measures, and applicable to a large field area. This is in line with previous studies in Finland as well as with recent results from the U.S. Kost et al. (2018) analyze the effect of spreading 2.2 tons of gypsum per hectare on dissolved P loading. Using tile flow water samples, they estimate that gypsum reduces the dissolved P initially by more than $40 \%$. Gradually, the effect starts declining being about 20\% after 1000 days. Also, King et al. (2016) analyze both surface and tile flow. They estimate that an application of 2.2 tons per hectare reduces the dissolved phosphorus loading by $36 \%$ and the total phosphorus by $38 \%$.

The Finnish agriculture has high potential to reduce phosphorus loads, as there are 0.5 million ha eligible clay soil for the use of gypsum. Provided a great share of farmers is willing to apply gypsum, Finnish agriculture would reduce annual phosphorus loads by approximately 300 tons to the sub-basins of the Baltic Sea. The promised load reduction is really considerable, and it is worth mentioning that in the end of 2018, the Finnish Government decided to provide extra funding for the Baltic Sea protection and allocated a great share of it to gypsum amendment in the catchment of the Archipelago Sea, targeting to 50-85 thousand hectares.

Farmers are keen to participate in agricultural water protection but possible issues hindering participation are liquidity and (for large farms) EU requirement for EU-wide public procurement. These features require reforming the current CAP framework. Furthermore, the becoming CAP system should facilitate ex-ante payment schemes for abating investments to overcome the financial challenge to farmers. An efficient measure for improving water quality should be easily available for each farm.

We note that the national decision by the Finnish Government at the end of 2018 to devote funding for gypsum amendment in the Archipelago Sea drainage basis would not have been possible within the CAP framework. The same holds true for the use of structural lime application in Sweden, where the government supports its application (Geranmayeh 2017). In general, CAP policy is ill- equipped in facilitating the introduction of these type of efficient water protection measures. Yet, the need for new innovations, including investments in water protection, are needed to boost reductions in nutrient loading in agriculture. So, the key question is how to reform CAP framework so that it would more easily facilitate introduction of innovations in the system. Our suggestion is to include a completely new option to CAP framework: national water (or more generally, environmental) protection investments. Member states would have to propose their measure, justify its use and then would be allowed to use CAP support based on the Commission's approval.

The majority of farmers have a highly positive experience from participation in the pilot project and in the development of a new agri-environmental measure. The project promoted co-operation and knowledge sharing, while the evidence of the permanence of the effect of trying and applying new methods in the farmer society is beyond this analysis. Also, the interpretation of the results is subject to the caution that a small sample may overemphasize the effect of one individual on the outcome.

During the project, the pilot participants were able to observe positive effects of gypsum amendment on soil, yield and adjacent waters. They also became aware that they have acquired technological and agronomic skills that are needed for the gypsum amendment. Both these aspects builds their trust on a new agri-environmental measure, which is crucial for adopting new practices. These experiences were actively communicated during the project in the media and through project reports, to make a societal impact.

Co-creation of the gypsum concept with farmers entailed documentation of experiences and deep discussions on how to develop the gypsum concept and include gypsum amendment in agricultural support systems. The SAVE pilot project demonstrated, first, the farmers' significant role in improving and mainstreaming new agricultural practices and agri-environmental measures and, second, the role of science in co-operation with stakeholders in the development of innovations to practice. The implementation of the pilot project can serve as an example on how to include new environmentally effective, socially acceptable and cost-effective measures in the policy frame, to be followed in the whole Baltic Sea Region.

Gypsum amendment provides an innovative measure for agricultural water protection, and these experiences from a large-scale pilot can serve as an example on how to organize the financing for the use of any innovations in agri-environmental sector. Allowing national innovations as part of the reformed CAP policy and payment scheme may boost environmental innovations and also enable finding the most suitable and environmentally effective 
measures for specific areas. With careful consideration of the reform of EU-wide payment schemes and international cooperation in spreading good practices and agri-environmental measures, the goal of the good ecological status of the Baltic Sea may be much closer than we have expected.

\section{Acknowledgements}

The authors thank two anonymous reviewers for constructive and insightful comments. Gypsum pilot in the River Savijoki was executed by the SAVE project in cooperation with the NutriTrade project, led by John Nurminen Foundation. We express our sincerest gratitude to the farmers in the pilot, as well as Terhi Ajosenpää (ProAgria), Juha Riihimäki (SYKE) and numerous others who helped to realize the Savijoki pilot. Funding from the Ministry of the Environment to SAVE and from the EU Central Baltic Programme to NutriTrade is gratefully acknowledged.

\section{References}

Aura, E., Saarela, K. \& Räty, M. 2006. Savimaiden eroosio. MTT:n selvityksiä 118. Agrifood Research Centre. 32 p. (in Finnish).

Bryant, R.B., Buda, A.R., Kleinman, P.J., Church, C.D., Saporito, L.S., Folmar, G.J., Bose, S. \& Allen, A.L. 2012. Using flue gas desulfurization gypsum to remove dissolved phosphorus from agricultural drainage waters. Journal of environmental quality 41: 664671. https://doi.org/10.2134/jeq2011.0294

Ekholm, P., Valkama, P., Jaakkola, E., Kiirikki, M., Lahti, K. \& Pietola, L. 2012. Gypsum amendment of soils reduces phosphorous losses in an agricultural catchment. Agricultural and Food Science 21: 279-291. https://doi.org/10.23986/afsci.6831

Geranmayeh, P. 2017 Strukturkalkning in stor skala - Vad krävs och vad kostar det? (Structure liming in large scale - requirements and costs) BalticSea2020. (in Swedish). http://balticsea2020.org/images/Bilagor/Strukturkalkning-i-stor-skala_Geranmayeh-2017.pdf Hyytiäinen, K. \& Ollikainen, M. 2012. Taloudellinen näkökulma Itämeren suojeluun. Ympäristöministeriön raportteja $22 / 2012$. (in Finnish).

Iho, A., Lankoski, J., Ollikainen, M., Puustinen, M. \& Lehtimäki, J. 2014. Agri-environmental auctions for phosphorus load reduction: experiences from a Finnish pilot. Australian Journal of Agricultural and Resource Economics 58: $205-222$. https://doi.org/10.1111/1467-8489.12049

Jaakkola, E., Tattari, S., Ekholm, P., Pietola, L., Posch, M. \& Bärlund, I. 2012. Simulated effects of gypsum amendment on phosphorus losses from agricultural soils. Agricultural and Food Science 21: 292-306. https://doi.org/10.23986/afsci.6773

Kallinen, A., Pirttijärvi, R., Saarnivaara, P. \& Heikkilä, E. 2016. Maatilojen kehitysnäkymät 2022 (Finnish farms: Outlook for development 2022). Suomen Gallup Elintarviketieto Oy. http://www.gallupnet.fi/maatila/Maatilojen_kehitysnakymat_2022.pdf 545 (Assessed 1 June 2016).

King, K.W., Williams, M.R., Dick, W.A. \& LaBarge, G.A. 2016. Decreasing phosphorus loss in tile-drained landscapes using flue gas desulfurization gypsum. Journal of environmental quality 45: 1722-1730. https://doi.org/10.2134/jeq2016.04.0132

Kosenius, A.-K. \& Ollikainen, M. 2019. Drivers of participation in gypsum treatment of fields as an innovation for water protection. Ecological Economics 157: 382-393. https://doi.org/10.1016/j.ecolecon.2018.12.002

Kost, D., Nester, J. \& Dick, W.A. 2018. Gypsum as a soil amendment to enhance water quality by reducing soluble phosphorus concentrations. Journal of Soil and Water Conservation 73: 22A- 24A. https://doi.org/10.2489/jswc.73.1.22A

Laamanen, M. 2016. Programme of measures for the development and implementation of the marine strategy in Finland 20162021. Reports of the Ministry of the Environment 5/2016. (in Finnish).

Lötjönen, S. \& Ollikainen, M. 2019. Multiple-pollutant cost-efficiency: Coherent water and climate policy for agriculture. Ambio 48: 1304-1313. https://doi.org/10.1007/s13280-019-01257-z

Ollikainen, M., Hasler, B., Elofsson, K., Iho, A., Andersen, H., Czajkowski, M. \& Peterson, K. 2019. Towards a Baltic Sea Socio-Economic Action Plan. AMBIO 48: 1377-1388. https://doi.org/10.1007/s13280-019-01264-0

Ollikainen, M., Ekholm, P., Punttila, E., Ala-Harja, V., Riihimäki, J., Puroila, S., Kosenius, A.-K. \& Iho, A. 2018. Gypsum treatment of fields as a means of water protection in agriculture. Information package. Helsinki, $2018.12 \mathrm{p}$.

Shortle, J. \& Horan, R.D. 2017. Nutrient pollution: A wicked challenge for economic instruments. Water Economics and Policy 3: 1650033. https://doi.org/10.1142/S2382624X16500338

Sitzmann, T., Ely, K., Brown, K.G., \& Bauer, K.N. 2010. Self-assessment of knowledge: A cognitive learning of affective measure? Academy of Management Learning \& Education 9. https://doi.org/10.5465/amle.9.2.zqr169

Uusitalo, R., Ekholm, P., Turtola, E., Pitkänen, H., Lehtonen, H., Granlund, K., Bäck, S., Puustinen, M., Räike, A., Lehtoranta, J., Rekolainen, S., Walls, M. \& Kauppila, P. 2007. Maatalous Itämeren rehevöittäjänä. Maa- ja elintarviketalous $96: 34$ s. (in Finnish).

Uusitalo, R., Ylivainio, K., Rasa, K., Kaseva, J., Pietola, L. \& Turtola, E. 2012. Gypsum effects on the movement of phosphorus and other nutrients through undisturbed clay soil monoliths. Agricultural and Food Science 21: 260-278. https://doi.org/10.23986/ afsci.4855 